\title{
Valuing Drinking Water Provision as an Ecosystem Service in the Neuse River Basin
}

\author{
Yoanna Kraus Elsin'; Randall A. Kramer²; and W. Aaron Jenkins ${ }^{3}$
}

\begin{abstract}
The valuation of ecosystem services such as drinking water provision is of growing national and international interest. The cost of drinking water provision is directly linked to the quality of its raw water input, which is itself affected by upstream land use patterns. This analysis employs the benefit transfer method to quantify the economic benefits of water quality improvements for drinking water production in the Neuse River Basin in North Carolina. Two benefit transfer approaches, value transfer and function transfer, are implemented by combining the results of four previously published studies with data collected from eight Neuse Basin water treatment plants. The mean net present value of the cost reduction estimates for the entire Neuse Basin ranged from \$2.7 million to \$16.6 million for a 30\% improvement in water quality over a 30-year period. The value-transfer approach tended to produce larger expected benefits than the function-transfer approach, but both approaches produced similar results despite the differences in their methodologies, time frames, study sites, and assumptions.
\end{abstract}

DOI: 10.1061/(ASCE)WR.1943-5452.0000058

CE Database subject headings: Costs; Water treatment; Benefit; Turbidity; Ecosystems; River basins; North Carolina.

Author keywords: Avoided costs; Water treatment costs; Benefit-cost analysis; Turbidity; Benefit transfer.

\section{Introduction}

Society increasingly recognizes the life support functions that ecosystems provide and without which human civilizations could not thrive. These include water purification, groundwater recharge, nutrient cycling, decomposition of wastes, regulation of climate, and maintenance of biodiversity. Derived from the physical, biological, and chemical processes at work in natural ecosystems, these functions are seldom experienced directly by users of the resource. Consequently, despite being essential to human welfare, these ecosystem services have rarely been valued in economic terms [National Research Council (NRC) 2005].

In the past 50 years, humans have transformed ecosystems more rapidly and intensively than ever before due to burgeoning populations and rising consumption rates. Although these changes have contributed substantially to human well-being, these benefits come with increasing costs, most notably the deterioration of many ecosystem services. The degradation of ecosystems could accelerate considerably during the first half of this century (Millennium Ecosystem Assessment 2005), if timely, effective measures are not taken.

This rapid degradation of global ecosystems owes in no small part to the lack an efficient pricing mechanism for the services

${ }^{1}$ Ph.D. Student, Dept. of Agricultural and Resource Economics, Univ. of Maryland, College Park, MD.

${ }^{2}$ Professor of Environmental Economics, Nicholas School of the Environment, Duke Univ., Durham, NC (corresponding author).

${ }^{3}$ Associate in Research for Economic Analysis, Nicholas Institute for Environmental Policy Solutions, Duke Univ., Durham, NC.

Note. This manuscript was submitted on August 3, 2008; approved on November 4, 2009; published online on November 6, 2009. Discussion period open until December 1, 2010; separate discussions must be submitted for individual papers. This paper is part of the Journal of Water Resources Planning and Management, Vol. 136, No. 4, July 1, 2010. CASCE, ISSN 0733-9496/2010/4-474-482/\$25.00. they provide. In land use decisions, the values of uses such as timber and agriculture often appear greater than those of conservation due to the failure to adequately estimate ecosystem service benefits (Kramer 2007). Nonmarket valuation methods aim to remedy this shortcoming. However, in many circumstances there is not enough time or resources to undertake original research to assess these values. For these cases a method called benefit transfer (BT), which is based on adjusting estimates of previous studies in other sites to calculate an estimate in a new site, is an alternative (Rosenberger and Loomis 2003). In this article, we use this method to estimate the benefits for potable water treatment in the Neuse River Basin related to an improvement in water quality as an ecosystem service.

Turbidity, a measure of suspended sediments in water, serves as the common water quality metric among the selected studies (Forster et al. 1987; Holmes 1988; Dearmont et al. 1998; Murray and Forster 2001). Land use decisions and land management influence the amount of sediment running off into the waterbody. High levels of turbidity can mean increased costs to treat drinking water at municipal facilities. Thus, one estimable value of sediment-reducing land management practices in upstream areas consists of these averted costs of water treatment.

Therefore, this study addresses the following question: How much money will be saved (or costs will be averted) in response to an increase in quality of the raw water used as input to the drinking water treatment process? These averted costs are a portion of the benefits from an improvement in raw water quality, as expressed by a reduction in turbidity.

We start by providing some relevant background information, including a short description of drinking water pollutants and treatment, some general information about BT method, and the principal characteristics of the study area, the Neuse River Basin in North Carolina. Next, we present a literature review with emphasis on the four studies used for the BT analysis. Then we detail the application of the two BT approaches, including assumptions and calculation descriptions. Finally, we present and 
discuss the results, before providing some conclusions about water quality as an ecosystem service.

\section{Background}

\section{Drinking Water Pollutants}

Any substance in the water can be a water contaminant or pollutant if it exceeds certain thresholds that make the water inadequate for its specific use. For drinking water purposes in the United States, the U.S. EPA has set standards for drinking water quality following requirements from the Safe Drinking Water Act. These drinking water standards are enforced on water treatment plants by the EPA, resulting in water treatment plants required to adjust their treatment depending on their incoming (raw) water quality to produce water that adheres to the standards.

Turbidity has been adopted as an easy and reasonably accurate measure of overall water quality (U.S. EPA 1999). This measure is therefore the principal target of the water treatment process, and while treating it, water treatment plants eliminate many other pollutants such as organic components and nutrients (U.S. EPA 1999). Turbidity is produced through the accumulation of solid particles in water. Soil erosion causes changes in water turbidity, as water passes through the land before it reaches the waterbody and takes solid particles with it. Sediment carried by runoff from crops, forests, pasture, and range accounts for approximately $68 \%$ of total suspended solids in waterways (Gianessi and Peskin 1981).

\section{Water Treatment Process}

To start the water treatment process, water is pumped into the plant from a lake, a reservoir or a river. The first step inside the plant is coagulation, the process of conditioning suspended solids particles to promote their agglomeration. This conditioning is achieved through chemical addition and mixing. Following coagulation, flocculation, the physical process of agglomerating small particles into larger ones so that they can be easily removed, is achieved by slower mixing. Subsequently, the water is slowed down further and the sedimentation process starts. During this process, water passes through several basins, the large particles formed during flocculation settle to the bottom of the basins while the clear water passes through to the filtration process. In the filtration process, the remaining solids are removed, passing through layers of sand and other solids that contain them. While water flows through the filters, the disinfection process takes place by adding disinfectant chemicals (such as chlorine) to kill bacteria and other potentially harmful microbes. The final required turbidity level is generally achieved after this process. Posttreatment consists of adding some finishing chemicals such as fluoride for dental protection, amines to control disinfection byproducts, or anticorrosives to protect the pipes. The water is often stored in clear wells during or after this process. Finally, the water is pumped or transported by gravity and distributed to the consumers (U.S. EPA 1999).

\section{$B T$}

In this section, we discuss the BT method, used in this study to value water quality improvements for drinking water provision. The BT method involves the use of environmental values estimated in one site (the "study site") as a proxy for values of the same good in another site (the "policy site") (Desvousges et al. 1998). Despite its name, the BT method is applicable to costs or averted costs (Pearce et al. 2006) as well as to benefits. In this study, we use BT to estimate averted costs in water treatment when an improvement in raw water quality occurs.

To undertake a BT, there are five general steps [simplified from Rosenberger and Loomis (2003)]:

1. Define the policy context; include the various characteristics of the policy site, what information is needed and in what units.

2. Locate and gather original research outcomes; conduct a thorough literature review and obtain copies of the relevant publications.

3. Screen the original research studies for relevance; compare the original research with the policy context including measures, units, quality, and define if adjustments are possible to obtain the desired information.

4. Select the value/s or functions to be transferred.

5. Transfer the function, value, range, calculate the average, or calculate the information needed based on the chosen studies.

The BT analysis undertaken in this study is based on both value-transfer and function-transfer approaches (Rosenberger and Loomis 2003). The value-transfer approach takes the point or average estimates of the values at the study site and applies them to the policy site. The function-transfer approach takes a function estimated at the study site, relating the value to be estimated with some characteristics at the study site, and applies it to the characteristics at the policy site to calculate a new value for the policy site.

\section{Neuse River Basin}

Our policy context, the Neuse River Basin, is entirely within North Carolina's boundaries. It originates in north-central North Carolina in Person and Orange counties and flows southeasterly until it reaches Craven and Pamlico counties. The river broadens and changes from a free-flowing river to a tidal estuary that eventually empties into the Pamlico Sound. Fig. 1 shows the basin and its counties. Of particular note is that the basin covers $6,235 \mathrm{mi}^{2}$, receives water from 18 counties and 74 municipalities, and had a population of 1,353,617 in 2000 (North Carolina Division of Water Quality 2002).

Fifty-six percent of the basin area is classified as forested/ wetland, $23 \%$ as cultivated cropland, $10 \%$ as water, $8 \%$ as urban, and the remaining percentage as pasture and managed herbaceous areas (North Carolina Division of Water Quality 2002).

According to the EPA Safe Drinking Water Information System (SDWIS) (U.S. EPA 2007), more than two-thirds of the basin's population served by public water systems relies on surface water systems. A total of approximately 138 MGD (million gallons per day) of surface water was withdrawn for public drinking water supply in the year 2002 [North Carolina Dept. of Environment and Natural Resources (NCDENR) Division of Water Resources (DWR) 2001]. The NC Water Supply Plan (NCDENR DWR 2001) observes that the Neuse River Basin supplies water to some of the state's fastest growing populations. Water demand in the Basin is projected to grow to 222 MGD by 2020.

\section{Previous Studies}

As land use within a river basin varies, instream water quality often changes, leading to changes in human welfare (benefits or costs). Since there is no existing market for water quality, indi- 


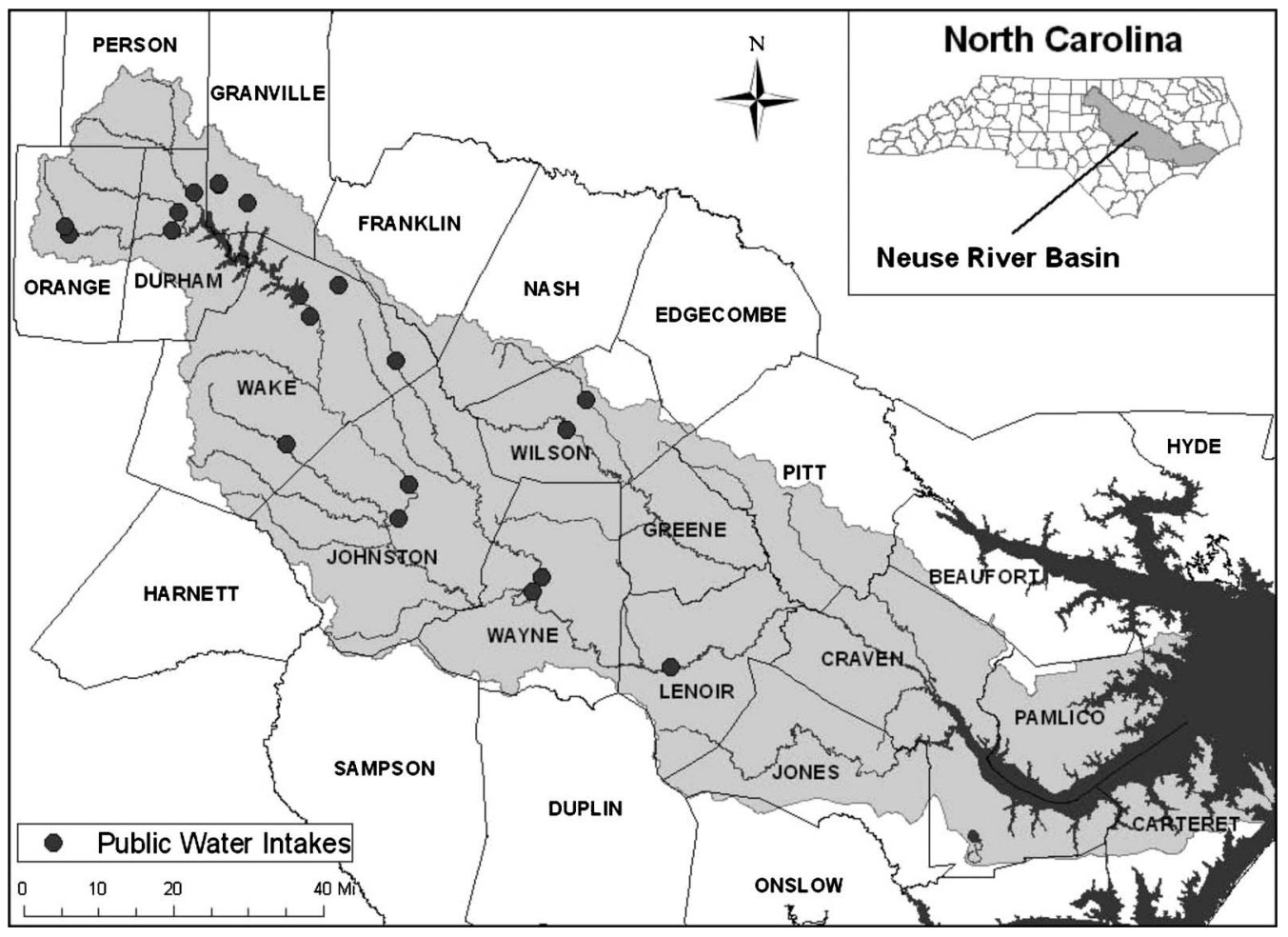

Fig. 1. Map of Neuse River Basin and public water intake locations

viduals cannot directly pay more for better water. However, the benefits and costs of water quality to producers and consumers can be estimated using environmental valuation methods.

Consumer benefits are typically measured with the metric willingness to pay (WTP), with two main approaches used to assess consumers' WTP for water quality improvements. The stated preference approach, which includes contingent valuation method and choice experiments, asks consumers how much they would pay for a given change in water quality, while the revealed preference approach infers a WTP value by analyzing observed consumer purchase or travel decisions. In the context of drinking water, the averting behavior method values quality by analyzing household expenditures to obtain potable water in response to degraded water conditions.

There are a number of previous studies that have evaluated drinking water quality benefits in terms of household WTP in different countries, considering different contaminants, and using different methods. A recent meta-analysis (Jenkins 2007) analyzed 16 such studies, half in developed countries and half in developing countries, and found adjusted mean household WTP values ranging from $\$ 0.95$ to $\$ 64.17$ annually for improvements in drinking water quality. Using surveys administered via phone, mail, or in-person, the studies employed choice experiments, contingent valuation method, or the averting behavior method to value water quality. The relevant pollutants differed significantly between the studies and included: arsenic, fecal coliform, bacteria, mineral contamination, organic contamination, nitrate contamination, copper, and giardia.

An alternative approach to measuring drinking water benefits is to examine changes in the cost of providing drinking water (Magara and Kunikane 1986). From the producers' perspective, a land use change that improves raw water quality in the waterbody, where withdrawals are made, can reduce the cost of treating the water to make it potable. These cost savings are a social benefit and are a straightforward way to link specific water quality changes to particular economic outcomes. Although most of the literature measures benefits from the consumers' perspective, the approach taken in the present analysis is based on studies conducted from the producer's perspective. This approach is chosen for several reasons: (1) the producer's perspective relates more directly to the stakeholders budget (e.g., the state's or the county's authorities); (2) WTP estimates from the consumer's perspective are often difficult to relate to specific changes in water quality; and (3) the drinking water consumer generally does not directly experience the impact of the changes in raw (untreated) water quality, since these changes are mitigated through the water treatment process.

Consequently, the studies most relevant for this study relate nonpoint source water contaminants from farming, in particular sediment that causes turbidity, to water treatment costs in surface water treatment plants. The goal of these studies is to measure the off-site costs of soil erosion. After searching through the Econlit and EVRI databases, four articles on the value of drinking water from a producer's perspective were found that (1) used a common water quality measure (turbidity) and (2) were conducted in the United States. These four articles, used for the current BT study, are Forster et al. (1987), Holmes (1988), Dearmont et al. (1998), and Murray and Forster (2001). The authors use turbidity in nephelometric turbidity units (NTUs), a measure of the deflected light passing through the water, as their water quality measure. These studies vary significantly in geographic location and variables included in the model but they all use surface water treatment plants as their units of evaluation. The studies consistently estimate positive elasticities of the costs of water treatment related to turbidity ranging between $0.07 \%$ and $0.3 \%$. Because of their importance in our BT analysis, each study is briefly described below and additional details are found in the Appendix.

Forster et al. (1987) the relationship between soil erosion and 
Table 1. Characteristics of Studies Selected for BT Analysis

\begin{tabular}{|c|c|c|c|c|}
\hline Study & Forster et al. (1987) & Holmes (1988) & Dearmont et al. (1998) & Murray and Forster (2001) \\
\hline Cost variable $(C)$ & Variable treatment costs & $\begin{array}{l}\text { Operation and } \\
\text { management costs }\end{array}$ & Variable treatment costs & Variable treatment costs \\
\hline Production variable $(S)$ & $\begin{array}{l}\text { Daily volume of water } \\
\text { produced }\end{array}$ & Water production per year & $\begin{array}{l}\text { Total volume treated per } \\
\text { month }\end{array}$ & Volume treated per year \\
\hline $\begin{array}{l}\text { Coefficient of production } \\
\text { variable }\end{array}$ & 0.657 & 0.85 & $-1.685 \times 10^{-8}$ & -0.17 \\
\hline $\begin{array}{l}T \text { value of production } \\
\text { coefficient }\end{array}$ & 24.333 & 25.38 & -4.1604 & -6.07 \\
\hline Water quality variable $(T)$ & Turbidity improvement & $\begin{array}{l}\text { Influent water turbidity } \\
\text { level }\end{array}$ & Turbidity of raw water & Average annual turbidity \\
\hline $\begin{array}{l}\text { Coefficient of water quality } \\
\text { variable }\end{array}$ & 0.119 & 0.07 & 0.0010 & 0.3 \\
\hline $\begin{array}{l}T \text { value of water quality } \\
\text { coefficient }\end{array}$ & 2.767 & 2.85 & $>1.95$ & 3.46 \\
\hline Equation form & Cobb-Douglas & Cobb-Douglas & Polynomial & Cobb-Douglas \\
\hline $\begin{array}{l}\text { Other variables included } \\
(Z)\end{array}$ & $\begin{array}{l}\text { Retention time, upstream } \\
\text { erosion estimate }\end{array}$ & $\begin{array}{l}\text { Pipe fitters wage level, } \\
\text { electricity costs index }\end{array}$ & $\begin{array}{l}\text { Raw water } \mathrm{pH} \text {, } \\
\text { contamination dummy, } \\
\text { average annual rainfall }\end{array}$ & Pesticide use \\
\hline
\end{tabular}

water treatment costs for 12 communities in Ohio's Corn Belt using a Cobb-Douglas cost function. The cost variable was chemical costs and the quality variable was turbidity improvement. Other variables taken into account were water volume, average retention time, and soil erosion. The elasticity of turbidity was reported to be $0.119 \%$.

Holmes (1988) assessed the effects of soil erosion due to agricultural activity on water treatment costs downstream. It divided the problem in two tasks. First, it related the costs of drinking water purification to water production, raw water quality and other treatment input prices. Second, it related water quality to sediment loading, stream flow and storage capacity. For this study we focused on the first part of Holmes study that estimated a Cobb-Douglas cost function relating water treatment costs and water quality. He used data from large water treatment plants nationwide (430 of the 600 largest water treatment plants). The costs were total operation and management costs including distribution and water acquisition, not including capital costs. The water quality variable was turbidity change in NTU. The other variables included in the model were labor and electricity costs. His estimated elasticity of cost to turbidity for the hedonic model is $0.07 \%$.

Dearmont et al. (1998) related chemical costs of water production in municipal water treatment plants in Texas to raw surface water quality. Data from 12 water treatment plants during three years (1988 to 1991) were used. An 1\% increase in turbidity was estimated to cause a $0.25-0.27 \%$ increase in chemical costs. They used a polynomial cost function taking into account the interaction of turbidity and $\mathrm{pH}$. Their cost variable was chemical cost calculated as chemicals used times their unit price. The other variables included in the model were total gallons produced, average annual rainfall and a contamination dummy.

Murray and Forster (2001) assessed the relationship between water treatment costs of the communities in the Great Lakes Basin and in particular the Maumee River Basin. The assessment was first conducted only with the Maumee data and then the function was adjusted for the data of the greater Great Lakes Basin. The authors estimated the relationships in three steps. They divided the variable costs in the chemical and nonchemical costs and related only the chemical ones to turbidity; estimating the chemical costs as a function of volume, pesticide use and raw water turbidity. (The model that we use for this study is based on 11 water treatment plants in the Maumee Basin.) The authors used a Cobb-Douglas cost equation and reported an elasticity of $0.30 \%$ related to turbidity.

\section{Methods}

To adjust the estimates from the study sites, the BT method requires data from the policy site. The articles identified for the BT are appropriate for the Neuse River Basin in that they all involve public surface water systems. The Neuse River Basin has 15 surface water treatment systems (Raleigh, Durham, Cary, Roxboro, Wilson, Goldsboro, Johnston, Smithfield, Apex, Butner, Hillsborough, Orange-Alamance, Wake Forest, Zebulon, and Creedmoor), 10 of which produce more than 2 MDG (NCDENR DWR 2002). We gathered data from 8 of the 10 the largest ones, through inperson, telephone and e-mail interviews with water treatment plant managers. The data gathered through this procedure included chemical costs, operating costs, and turbidity. The data on water production were obtained from the North Carolina Department of the Environment and Natural Resources (NCDENR) 2002 local water supply plans.

We selected two BT approaches, a value transfer and a function transfer and applied these to four different studies. This allowed us to compare and average the estimates. To describe these approaches we will explain the common features exhibited by all the models selected from the chosen studies. The main characteristics of the four selected studies are presented in Table 1. All the studies used models with a general form that included: a cost variable as a dependant variable $(C)$, a water quality variable $(T)$, a production variable $(S)$, and a vector of other independent variables $(Z)$.

The dependent variable is the variable cost of treatment $(C)$, represented either by total operation and management costs in the Holmes (1988) study or by total chemical costs in Dearmont et al. (1998) and in Murray and Forster (2001). Forster et al. (1987) uses variable treatment costs noting that they are mostly chemical 
costs. The transfer studies use costs per unit of time or cost per unit of volume and these differences are standardized in our calculations. Since we are interested in the change in the costs, rather than absolute value of costs, and the changes are assumed to be principally attributable to the chemical costs (the Holmes model results are assumed to be comparable with the rest of the models). Costs were inflation adjusted to 2006/2007 dollars using the producer price index (PPI). Holmes (1988) and Murray and Forster (2001) employed turbidity of the intake water in NTU as the water quality variable. Forster et al. (1987) and Dearmont et al. (1998) used difference in raw water turbidity and finished water turbidity in NTU. Since treated water has very low turbidity and this turbidity level should be very similar between plants and times of the year, this difference between the turbidity measures should not affect the use of the studies for the BT. All the studies included the amount of water treated per time period (in gallons or similar volume unit per time) as the measure for production of the system. Adjustments are made in our calculations to reflect the differences in the time and volume units used to measure the production in the different studies.

The goodness of fit for the regressions produced by the transfer studies was generally strong, indicating that the drinking water quality relationships estimated were effectively explained by their models. Forster et al. (1987) and Holmes (1988) both had $R^{2}$ values of 0.84 , while Murray and Forster (2001) showed an $R^{2}$ of 0.56 and Dearmont et al. (1998) of 0.19. In each case, the coefficients for the production variable and the water quality variable were significantly different from zero at the 5\% level or better, further validating their use in the BT exercise.

The cost function models in the four studies can be generalized as

$$
C_{t i}=f\left(T_{t i}, S_{t i}, \vec{Z}_{t i}\right)
$$

where $C_{t i}=$ variable costs; $T_{t i}=$ water quality variable; $S_{t i}$ =production variable; $\vec{Z}_{t i}=$ vector of other variables; $t=$ time period; and $i=$ treatment plant. The function $f=$ Cobb-Douglas function in 3 of the studies, but Dearmont et al. (1998) use a polynomial cost function.

\section{Value Transfer}

For the first benefits transfer approach, the value transfer, we took the elasticity of the water quality variable from each study and multiplied it by the true variable costs for each of the Neuse Basin water treatment plants to estimate the change in costs for each plant and each study. In this approach we assumed that the elasticities in the previous studies were transferable to the Neuse Basin. We also assumed the relationship between turbidity and costs was linear within the range of turbidity considered.

For the first approach, each turbidity cost elasticity is given by

$$
\begin{aligned}
\varepsilon_{j} & =\frac{\Delta C_{j}}{\Delta T_{j}} * \frac{\bar{T}_{j}}{\bar{C}_{j}} \Rightarrow \varepsilon_{j} * \frac{\bar{C}_{j}}{\bar{T}_{j}} * \Delta T_{j}=\Delta C_{j} \Rightarrow \varepsilon_{j} * \bar{C}_{j} * \frac{\Delta T_{j}}{\bar{T}_{j}}=\Delta C_{j} \\
& \Rightarrow \Delta C_{j}=\varepsilon_{j} * \bar{C}_{j} * \% \Delta T_{j}
\end{aligned}
$$

where $\bar{T}_{j}=$ average turbidity at the study site; $\bar{C}_{j}=$ average costs at the study site; $\Delta C_{j}=$ change in costs at the study site; $\Delta T_{j}$ $=$ change in turbidity at the study site; $\varepsilon_{j}=$ elasticity cost turbidity in study $j$; and $\% \Delta T_{i}=$ percentage change in turbidity at intake point at plant $i=\Delta T_{j} / \bar{T}_{j}$.
Based on the previous formula, we substituted the average cost at the study site $(j)$ by the average cost at plant $(i)$ and did the same with the percentage change in turbidity. The calculation used for each study $(j)$ and each plant $(i)$ was then

$$
\Delta \hat{C}_{i j}=\varepsilon_{j} * \bar{C}_{i} * \% \Delta T_{i}
$$

where $\Delta \hat{C}_{i j}=$ the estimated change in cost from study $j$ for plant $i$; $\varepsilon_{j}=$ elasticity cost turbidity in study $j ; \bar{C}_{i}=$ average costs at plant $i$ (from plant surveys); and $\% \Delta T_{i}=$ percentage change in turbidity at intake point at plant $i$.

\section{Function Transfer}

For the second approach, the function transfer, we took the estimated function for each of the previous studies and applied the mean values for all of the other variables $(Z)$ in each model. Only the production variable $(S)$ was replaced with the true values for each plant in the Neuse Basin instead of the study site's average. The cost was calculated two times: with the turbidity levels before and after the change in raw water quality (turbidity). The differences between the two cost estimates were used to obtain the change in the costs for each plant and for each study. Here, not only did we assume that the function is transferable to the Neuse, but also that the average values for all the rest of the variables $(Z)$, other than the production variable and the turbidity, were transferable too.

For each study $i$ and plant $j$ the estimated change in cost is given by

$$
\Delta \hat{C}_{i j}=\hat{C}_{i j}^{1}-\hat{C}_{i j}^{0}
$$

and

$$
\begin{aligned}
& \hat{C}_{i j}^{0}=f\left(T_{i}^{0}, \bar{S}_{i}, \overline{\vec{Z}}_{j}\right) \\
& \hat{C}_{i j}^{1}=f\left(T_{i}^{1}, \bar{S}_{i}, \overline{\vec{Z}}_{j}\right)
\end{aligned}
$$

where $\Delta \hat{C}_{i j}=$ the estimated change in cost from study $j$ for plant $i$; $\hat{C}_{i j}^{0}=$ the estimated cost from study $j$ for plant $i$ before the change in turbidity; $\hat{C}_{i j}^{1}=$ the estimated cost from study $j$ for plant $i$ after the change in turbidity; $T_{i}^{0}=$ turbidity at plant $i$ before change in turbidity; $T_{i}^{1}=$ turbidity at plant $i$ after change in turbidity; $\bar{S}_{i}$ $=$ average of the production variable at plant $i$ at the policy site (from plant surveys); and $\overline{\vec{Z}}_{j}=$ vector of average values of the other variables at study site of study $j$.

Ideally, we would know averages for all of the $Z$ values for the policy site and substitute those into the cost equation. However, as in most BT settings, we were faced with information limitations.

\section{Benefit Aggregation and NPV}

After calculating the yearly estimates for each treatment plant $n$ the Neuse Basin for all four studies, some additional calculations were made to obtain estimates of the 30-year net present value (NPV) of the benefits for the whole basin.

For each study, we aggregated all the benefits across all the water treatment plants surveyed and obtained total benefits for the 
plants surveyed. For each study $j: \Delta \hat{C}_{j}=\Sigma_{i} \Delta \hat{C}_{i j}$. Then $\Delta \hat{C}_{j}$, the estimated change in costs for all the surveyed plants for study $i$, was divided by the total production of all the water treatment plants surveyed to estimate an average per million gallon treatment cost reduction (or benefit) for the Neuse Basin for study $j$ : $\Delta \hat{c}_{j}=\Delta \hat{C}_{j} / P$, with $\mathrm{P}$ being the production from all the surveyed plants. This per million gallon estimate can be averaged among studies to attain a unique number for the whole Neuse: $\Delta \hat{c}$ $=\Sigma_{j}\left(\Delta \hat{c}_{j} / \#\right.$ studies $)$. Finally, we multiplied this per million gallon benefit by the total Neuse surface water production to attain the final estimate for the total basin. (The plants surveyed account for approximately $90 \%$ of the total Basin's production.) We also multiplied the average per million gallon treatment cost reduction for the Neuse Basin for study $j$ by the total Neuse water production to generate an estimate for the Neuse for each study independently.

The calculation described provided us with annual benefits. To compute a NPV, we calculated future cost reductions based on a basin-wide profile of turbidity change through time. The NPV is calculated for a 30-year period, assuming that the total change in turbidity levels will take 5 years to be realized and that during these years the turbidity decreases linearly. To calculate the NPV, we use a $4 \%$ discount rate, which is common in the environmental economics literature. This approach ignores any drinking water production increases due to population growth, and thus yields a conservative estimate.

The cost reductions are calculated for several scenarios of turbidity reductions. We used a range from 5 to $30 \%$ to represent reductions in turbidity at water intake points. This range was chosen based on results of studies done at the Yadkin Basin in western North Carolina for the years of 1951 to 1990. Korfmacher (1996) found that during these years the area in row crops decreased from 11.52 to $5.6 \%$ as more land transitioned to forest and pasture. According to this study, the urbanized area grew from 5 to $18 \%$ in parallel to these row crop changes. In particular, between 1955 and 1988, in areas where more than $98 \%$ of the cultivated land was located, the average erosion rates declined between 13 and 43\%. Richter et al. (1995) estimated a 30\% reduction in sediment carried by the Yadkin River from the 1950s to the 1990s.

The two BT approaches are different in the variables used and also in the assumptions. The assumptions differ since the first approach assumes that the elasticities of turbidity for each water plant in the Neuse River basin are the same as the ones reported for each study. The second approach assumes that the relationship between costs adjusted for turbidity and size (MGD), but with the rest of the variables at the average levels of the study sites, represents the cost relationship at the Neuse River Basin. Essentially, for the second approach we are calculating the costs using the functions provided, while in the first approach we are using the costs provided and only calculating the change.

\section{Comparison}

To gain insight about the validity of the transfers, we compared the principal variables, turbidity and water production, for the BT between the policy and the study sites. An analysis was undertaken comparing the ranges covered by the water treatment plants at the Neuse and the plants in the transfer studies. The ranges of most of the studies had considerable overlap with the ranges of the Neuse facilities (see Table 2). In general, the Neuse values are
Table 2. Turbidity and Water Production for Water Treatment Plants in the Policy and Study Sites

\begin{tabular}{lccccc}
\hline & \multicolumn{2}{c}{ Turbidity $(\mathrm{NTU})$} & & \multicolumn{2}{c}{ Production $(\mathrm{MGD})$} \\
\cline { 2 - 3 } \cline { 5 - 6 } Ranges & Minimum & Maximum & & Minimum & Maximum \\
\hline Neuse & 3.5 & 20.0 & & 1.0 & 50.0 \\
Forster & 0.3 & 38.9 & & 0.9 & 6.2 \\
Holmes $^{\mathrm{a}}$ & 0.0 & 32.3 & & 0.0 & 143.5 \\
Dearmont & 5.9 & 89.2 & & 0.3 & 29.4 \\
Murray & 3.0 & 97.7 & & 0.1 & 14.1 \\
\hline
\end{tabular}

${ }^{\mathrm{a}}$ Not reported, so estimated using the reported means and SDs.

contained within the minimum and maximum range of the transfer studies' combined points for production and turbidity.

In Fig. 2, we compare the annual average variable treatment and O\&M (operation and management) costs for the plants in the Neuse Basin and in the BT studies. The numbers are not the estimated costs but the surveyed and reported costs at the study and policy sites, with the exception of the treatment costs for Holmes that were estimated ex-post in that study. While Neuse Basin average O\&M costs are a little lower than the others', average treatment costs collected in the Neuse Basin are somewhat higher than those in the transfer studies. This is explained by chemical costs having risen at a rate faster than the overall rate of inflation. From 1996 to 2006, the increase in the PPI for all commodities was $30.1 \%$, whereas the PPI for industrial chemicals increased by $65.5 \%$. We used the broader PPI to inflate prices in this study because the cost variable is not simply chemical costs. This change in chemical costs would be implicit in elasticity transfer since it uses Neuse Basin costs, but not so in the function transfer.

\section{Results}

In this section, we present the NPV results for the Neuse Basin costs reductions resulting from decreases in turbidity of 5 to $30 \%$. The results are presented individually for each study and also as an average of all the studies included (see Table 3 and Fig. 3).

A 5\% drop in turbidity throughout the Neuse River Basin would imply benefits in NPV between $\$ 395,643$ and $\$ 2,763,085$. For a $30 \%$ change in turbidity the NPV of the future benefits would be between $\$ 2,616,615$ and $\$ 16,578,512$. Murray's elasticity transfer approach consistently yields the highest estimates, while Dearmont's function-transfer approach produces the lowest estimates.

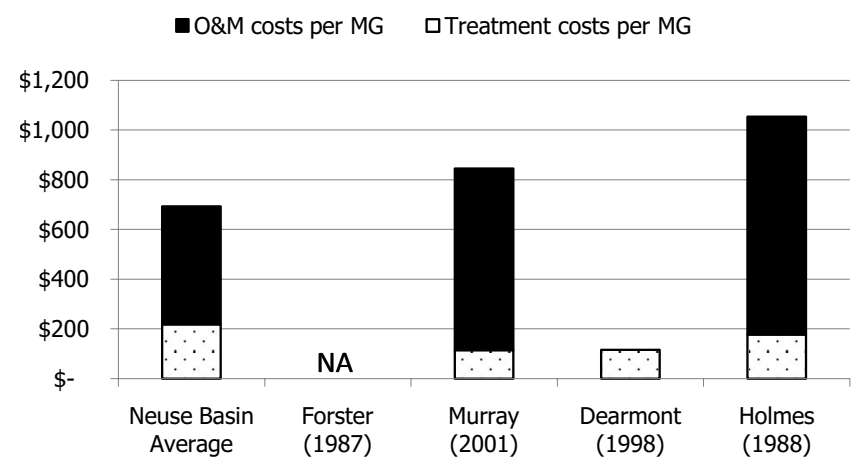

Fig. 2. Average annual costs per million gallons (MG) for BT studies and Neuse Basin water treatment plants 
Table 3. NPV of Costs Reductions for Different Percentage Decreases in Turbidity

\begin{tabular}{|c|c|c|c|c|c|c|}
\hline $\begin{array}{l}\text { Turbidity } \\
\text { decrease } \\
(\%)\end{array}$ & NPV & $\begin{array}{l}\text { Average } \\
(\$)\end{array}$ & $\begin{array}{l}\text { Forster } \\
(\$)\end{array}$ & $\begin{array}{l}\text { Murray } \\
(\$)\end{array}$ & $\begin{array}{l}\text { Dearmont } \\
(\$)\end{array}$ & $\begin{array}{l}\text { Holmes } \\
(\$)\end{array}$ \\
\hline \multirow[t]{2}{*}{5} & Elasticity transfer & $2,094,449$ & $1,105,234$ & $2,763,085$ & $2,302,571$ & $2,206,906$ \\
\hline & Function transfer & $1,139,636$ & 395,643 & $2,236,785$ & 424,747 & $1,501,368$ \\
\hline \multirow[t]{2}{*}{10} & Elasticity transfer & $4,188,898$ & $2,210,468$ & $5,526,170$ & $4,605,142$ & $4,413,812$ \\
\hline & Function transfer & $2,322,789$ & 809,169 & $4,553,516$ & 854,002 & $3,074,468$ \\
\hline \multirow[t]{2}{*}{20} & Elasticity transfer & $8,377,797$ & $4,420,936$ & $11,052,341$ & $9,210,284$ & $8,827,625$ \\
\hline & Function transfer & $4,837,473$ & $1,697,669$ & $9,458,067$ & $1,726,136$ & $6,468,019$ \\
\hline \multirow[t]{2}{*}{30} & Elasticity transfer & $12,566,695$ & $6,631,404$ & $16,578,512$ & $13,815,426$ & $13,241,438$ \\
\hline & Function transfer & $7,587,988$ & $2,684,803$ & $14,789,961$ & $2,616,615$ & $10,260,573$ \\
\hline
\end{tabular}

To convey the relationship between the different studies and approaches, we graphed the NPV for all the studies as well as the averages across the studies for different levels of turbidity change. Fig. 3 shows consistently higher estimates for the elasticity transfer than the function transfer. This may be explained by the fact that chemical costs have risen more quickly than the overall rate of inflation and that chemical cost inflation is accounted for in the elasticity transfer, but not in the function transfer. In particular, the Dearmont study has the largest difference between the two approaches. This is related to the use of a polynomial function in Dearmont, which implies a different elasticity for different water production levels. This is in contrast to the Cobb-Douglass functions used in the other three transfer studies, which have the same elasticity regardless of the other variables.

\section{Discussion}

The consistency of the estimates obtained from the different studies is remarkable considering the differences in model specification, geographical location, variables included in the model and years in which they were conducted. However, it is worth noting that in most of the study sites, agriculture is more prominent than in the Neuse Basin, where the land cover is over $50 \%$ forest. Because of the predominantly agricultural land use, pesticides are an important part of the water treatment in those other study sites, and this difference could mean a general bias in the estimates.

Additionally, the similarity of the estimates from the two different BT approaches undertaken is noteworthy in light of their very different assumptions as explained in the methods section.

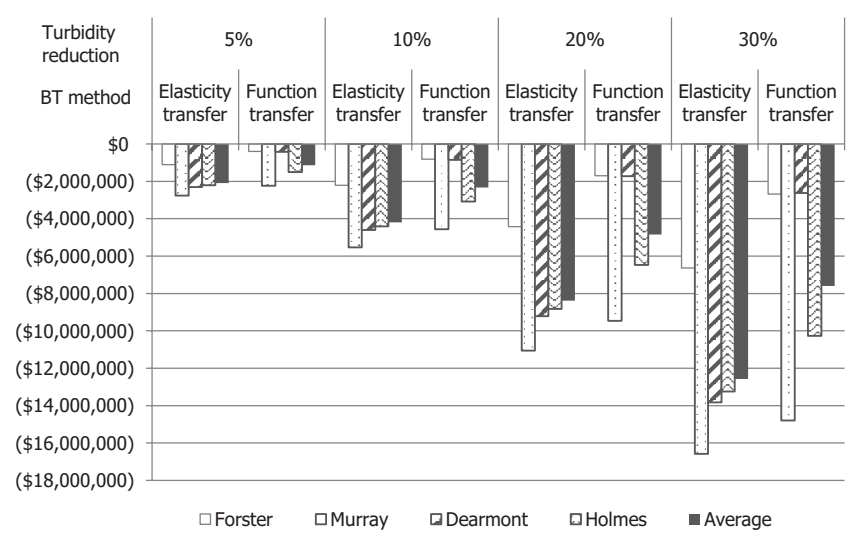

Fig. 3. Water treatment cost savings in NPV by levels of turbidity reduction and $\mathrm{BT}$ method
The elasticity method assumes linearity in the costs-turbidity relationship and direct transferability of the estimated elasticities (costs/turbidity) from the study sites to the Neuse Basin. The function-transfer approach assumes that all the variables other than water production and turbidity have similar means in the Neuse as at the study sites.

Since the final estimates are calculated as averages of the four studies used, one of the most important assumptions made in this BT is that the Neuse's variables, both dependent and independent, are within the range of the estimates of the studies used. Some support for this assumption is presented in Table 3, where the production and turbidity values for the Neuse's water treatment plants are shown to lie within the average values yielded by the studies. However, other limitations of our approach are worth discussing since they could potentially affect the use of the estimates provided by this analysis.

First, this study only presents benefits to the population served by public surface drinking water facilities. As mentioned in the background section of this study, there is a considerable proportion of the population that is not served by this type of system. Specifically, about one third of the population in the Neuse Basin relies on groundwater. Since land use changes that affect surface water quality also could affect groundwater quality, our numbers are underestimates of the total benefits to drinking water ecosystem services that would be obtained through an improvement in water quality in the basin.

Second, two of the four studies used for the BT only measured changes in chemical costs. Although chemicals are a large component of the variable costs in the studies used, there are other variable costs related to the quality of raw water inputs. Higher turbidity could affect costs by producing more sludge and increasing sludge removal costs, including for electricity and sludge disposal. Filter backwash time might also be affected. More turbidity means more frequent washing of the filters, implying partially stopping the process and using electricity to run the pumps backward. Many treatment plants that draw from rivers also have presettlement reservoir which can silt up. Storage capacity is lost more quickly if turbidity increases. Thus, these additional variable costs related to turbidity could increase the treatment costs and therefore make our reduction estimates lower than actual cost reductions.

Third, Forster et al. (1987) also noted that suspended sediment (turbidity) is only one of the variables affecting the operation of a treatment plant. Other water quality variables, such as acidity $(\mathrm{pH})$, hardness, and total organic content (TOC), can also play a role in the costs of running a surface water facility. In particular for this case, TOC was a concern mentioned in several of the Neuse River treatment plant operator interviews. Stricter state 
standards have promoted adjustments in their processes to deal with TOCs. Some of the surveyed plants have considered or implemented adjustments to the treatment process, including activated carbon and ozone as well as new additions to treatment such as ultraviolet treatment and covering the reservoirs to mitigate algae blooms. The models used for the BT here are based on turbidity as the only measure of water quality and do not account for the potential effects of other pollutants.

\section{Conclusions}

The provision of drinking water is an ecosystem service influenced by water quality and by the upstream land use patterns that affect water quality. Turbidity levels in waterbodies respond to changes in land practices, such as land use type, farming method and residential and commercial development. Increased turbidity in raw water, the principal input in drinking water production, can result in higher costs borne by water treatment facilities. If policies are undertaken to put land into conservation practices, resulting reductions in treatment costs stemming from reduced turbidity levels is a measureable ecosystem service benefit for society.

As the estimation of ecosystem benefits is often limited by time and resources, the BT method holds the promise of using previous research to produce plausible economic values for new sites of interest. Timely benefit estimation studies can inform decision makers and promote better ecosystem management. This article has demonstrated an approach to use prior drinking water treatment studies conducted in other areas and to apply them to a new study site - the Neuse River Basin in North Carolina. It provides an estimated range for the benefits of water quality improvements for drinking water production. This study also brings attention to the fact that few drinking water treatment studies have been conducted to date and furnishes a useful context for comparison of any upcoming studies. Future research may focus on a BT study that incorporates water variables other than turbidity. In particular, TOC levels appear to affect treatment costs, are closely linked to runoff of nutrients nitrogen and phosphorus, and are a pressing concern in the Neuse River Basin and numerous other river basins.

\section{Appendix. Details of the Cost Models Used for BT Analysis}

This appendix provides the cost models as estimated by the original study authors and a description of the variables used. These 4 models are used in the current study to conduct the BT analysis.

\section{Forster Study}

$$
\begin{aligned}
\operatorname{Ln} C= & -0.562+0.657 \ln S+0.141 \ln R+0.119 \ln T \\
& +0.406 \ln E
\end{aligned}
$$

\begin{tabular}{|c|c|c|c|c|}
\hline $\begin{array}{l}\text { Variable } \\
\text { name in the } \\
\text { original } \\
\text { study }\end{array}$ & $\begin{array}{l}\text { Variable name } \\
\text { according to } \\
\text { the } \\
\text { generalization }\end{array}$ & Description & $\begin{array}{c}\text { Study } \\
\text { average }\end{array}$ & Units \\
\hline C & C & $\begin{array}{c}\text { Variable } \\
\text { treatment } \\
\text { costs } \\
\text { (chemical) }\end{array}$ & NA & $\$$ per day \\
\hline$S$ & $S$ & $\begin{array}{l}\text { Daily } \\
\text { volume }\end{array}$ & 933 & $\begin{array}{c}\text { Thousand } \\
\text { gallons per } \\
\text { day }\end{array}$ \\
\hline$R$ & $Z 1$ & $\begin{array}{l}\text { Retention } \\
\text { time }\end{array}$ & 331 & Days \\
\hline$T$ & $T$ & $\begin{array}{c}\text { Turbidity } \\
\text { improvement }\end{array}$ & 3.8 & NTU \\
\hline$E$ & $Z 2$ & $\begin{array}{l}\text { Upstream } \\
\text { erosion } \\
\text { estimate }\end{array}$ & 2 & Tons/acre \\
\hline
\end{tabular}

Forster et al. (1987) Cost Model

\section{Holmes Study}

$\ln \mathrm{OMX}=-2.55+0.85 \ln Y+0.07 \ln Q+0.77 \ln W+0.23 \ln E$

where

\begin{tabular}{|c|c|c|c|c|}
\hline $\begin{array}{l}\text { Variable } \\
\text { name in the } \\
\text { original } \\
\text { study }\end{array}$ & $\begin{array}{l}\text { Variable name } \\
\text { according to } \\
\text { the } \\
\text { generalization }\end{array}$ & Description & $\begin{array}{c}\text { Study } \\
\text { average }\end{array}$ & Units \\
\hline OMX & C & $\begin{array}{c}\text { Operation } \\
\text { and } \\
\text { management } \\
\text { costs }\end{array}$ & 10,719 & $1,000 \$ / \mathrm{yr}$ \\
\hline Y & $S$ & $\begin{array}{l}\text { Water } \\
\text { production }\end{array}$ & 15,758 & $\begin{array}{l}\text { million } \\
\text { gallons/yr }\end{array}$ \\
\hline$Q$ & $T$ & $\begin{array}{l}\text { Influent } \\
\text { water } \\
\text { turbidity } \\
\text { level }\end{array}$ & 13.27 & NTU \\
\hline$W$ & $Z 1$ & $\begin{array}{l}\text { Pipe fitters } \\
\text { wage level }\end{array}$ & 6.76 & $\$ / h r$ \\
\hline E & $Z 2$ & $\begin{array}{l}\text { Electricity } \\
\text { costs index }\end{array}$ & 84.46 & $\$ / \mathrm{MWh}$ \\
\hline
\end{tabular}

\section{Holmes (1988) Cost Model}

\section{Dearmont Study}

$$
\begin{aligned}
\mathrm{CWTC}= & -0.1314-1.6950 \times 10^{-8} \times T G+1.3496 \times 10^{-4} \times(T \\
& \times \mathrm{pH})-1.5130 \times 10^{-7} \times(T \times \mathrm{pH})^{2}+5.3013 \times 10^{-11} \\
& \times(T \times \mathrm{pH})^{3}+0.0947 \times C D+5.6024 \times 10^{-3} \times A R
\end{aligned}
$$


Dearmont et al. (1998) Model

\begin{tabular}{|c|c|c|c|c|}
\hline $\begin{array}{l}\text { Variable } \\
\text { name in the } \\
\text { original } \\
\text { study }\end{array}$ & $\begin{array}{l}\text { Variable name } \\
\text { according to } \\
\text { the } \\
\text { generalization }\end{array}$ & Description & $\begin{array}{c}\text { Study } \\
\text { average }\end{array}$ & Units \\
\hline CWTC & C & $\begin{array}{l}\text { Chemical } \\
\text { water } \\
\text { treatment } \\
\text { costs per } \\
\text { volume } \\
\text { treated }\end{array}$ & 88.38 & $\begin{array}{l}\$ / 1,000 \\
\text { gallons }\end{array}$ \\
\hline$T G$ & $S$ & $\begin{array}{c}\text { Total } \\
\text { volume } \\
\text { treated }\end{array}$ & 222,350 & $\begin{array}{l}1,000 \\
\text { gallons per } \\
\text { month }\end{array}$ \\
\hline$T$ & $T$ & $\begin{array}{l}\text { Turbidity of } \\
\text { raw water }\end{array}$ & 23.05 & NTU \\
\hline $\mathrm{pH}$ & $Z 1$ & $\begin{array}{c}\text { Raw water } \\
\text { pH }\end{array}$ & 8 & Units \\
\hline$C D$ & $Z 2$ & $\begin{array}{c}\text { Contamination } \\
\text { dummy }\end{array}$ & $5 / 12=0.41$ & Binary \\
\hline$A R$ & $Z 3$ & $\begin{array}{l}\text { Average } \\
\text { annual } \\
\text { rainfall }\end{array}$ & $\begin{array}{l}\text { Between } 18 \\
\text { and } 40 \sim 24\end{array}$ & Inches \\
\hline
\end{tabular}

\section{Murray Study}

$$
\ln \mathrm{ACC}=7.97-0.17 \ln V+0.29 \ln P U+0.30 \ln T
$$

where

\section{Murray and Forster (2001) Table}

\begin{tabular}{|c|c|c|c|c|}
\hline $\begin{array}{l}\text { Variable } \\
\text { name in the } \\
\text { original } \\
\text { study }\end{array}$ & $\begin{array}{l}\text { Variable name } \\
\text { according to } \\
\text { the } \\
\text { generalization }\end{array}$ & Description & $\begin{array}{c}\text { Study } \\
\text { average }\end{array}$ & Units \\
\hline $\mathrm{ACC}$ & C & $\begin{array}{l}\text { Chemical } \\
\text { cost per } \\
\text { volume }\end{array}$ & 137.04 & $\begin{array}{l}\text { \$/million } \\
\text { gallons }\end{array}$ \\
\hline$V$ & $S$ & $\begin{array}{l}\text { Volume } \\
\text { treated }\end{array}$ & $1,226,000$ & gallons/yr \\
\hline$P U$ & $Z 1$ & $\begin{array}{c}\text { Pesticide } \\
\text { use }\end{array}$ & 1.66 & $\begin{array}{l}\text { pounds per } \\
\text { acre }\end{array}$ \\
\hline$T$ & $T$ & $\begin{array}{l}\text { Average } \\
\text { annual } \\
\text { turbidity }\end{array}$ & 37.51 & NTU \\
\hline
\end{tabular}

\section{References}

Dearmont, D., McCarl, B. A., and Tolman, D. A. (1998). "Costs of water treatment due to diminished water quality: A case study in Texas."
Water Resour. Res., 34, 849-853.

Desvousges, W., Johnson, F. R., and Banzaf, H. S. (1998). Environmental policy analysis with limited information: Principles and applications of the transfer method, W. E. Oates and H. Folmer, eds., Edward Elgar Publishing, Cheltenham, U.K.

Forster, L., Bardos, C. P., and Southgate, D. D. (1987). "Soil erosion and water treatment costs." J. Soil Water Conserv., 42, 349-352.

Gianessi, L. P., and Peskin, H. M. (1981). "Analysis of national water pollution control policies. 2: Agricultural sediment." Water Resour. Res., 17, 9-27.

Holmes, T. P. (1988). "The offsite impact of soil erosion on the water treatment industry." Land Econ., 64, 356-366.

Jenkins, W. A. (2007). "Economic valuation of water quality services: The natural capital project internship." MS thesis, Univ. of WisconsinMadison, Madison, Wis.

Korfmacher, K. (1996). "Changes in land use and water quality in the Yadkin River Basin, NC 1951-1990: A time-series/GIS analysis." Ph.D. dissertation, Duke Univ., Durham, N.C.

Kramer, R. A. (2007). "Economic valuation of ecosystem services." Chapter 11 in Sage Handbook on Environment and Society, J. Pretty, et al., eds., Sage Publications, New York.

Magara, Y., and Kunikane, S. (1986). "Cost analysis of the adverse effect of algal growth in waterbodies on drinking water supply." Ecol. Modell., 31, 303-313.

Millennium Ecosystem Assessment. (2005). Ecosystems and human wellbeing: Synthesis, W. V. Reid, ed., Island Press, Washington, D.C.

Murray, C., and Forster, L. (2001). "A study of pesticide use, farming practices, and community drinking water treatment costs in the Maumee and Great Lakes Basins." Rep. Series AEDE-RP-0013-01, Agricultural, Environmental, and Development Economics, Ohio State Univ., Columbia, Ohio.

National Research Council (NRC). (2005). Valuing ecosystem services: Toward better environmental decision-making, National Academies Press, Washington, D.C.

North Carolina Dept. of Environment and Natural Resources (NCDENR) Div. of Water Resources (DWR). (2001). "NC water supply plan Neuse River Basin summary." 〈http://www.ncwater.org/Reports_ and_Publications/swsp/swsp_jan2001/swsp_j01.php (Aug. 15, 2007).

North Carolina Div. of Water Quality. (2002). "Basinwide planning program: 2002 Neuse River basinwide water quality plan." 〈http:// h2o.enr.state.nc.us/basinwide/Neuse/2002/plan.htm〉. (Aug. 15, 2007).

Pearce, D. W., Atkinson, G., and Mourato, S. (2006). "Cost-benefit analysis and the environment: recent developments." Organization for economic co-operation and development, Paris.

Richter, D. D., Korfmacher, K., and Nau, R. (1995). "Decreases in Yadkin River Basin sedimentation: Statistical and geographic tine-trend analyses, 1951-1990." WRRI Project No. 70123, Univ. of North Carolina.

Rosenberger, R. S., and Loomis, J. B. (2003). "Benefit transfer.” A primer in nonmarket valuation, P. A. Champ, K. J. Boyle, and T. C. Brown, eds., Kluwer Academic, Dordrecht, The Netherlands, 445-482.

U.S. EPA. (1999). "Guidance manual for compliance with the interim enhanced surface water treatment rule: Turbidity provisions." EPA815-R-99-010, Washington, D.C., 〈http://www.epa.gov/safewater/ mdbp/mdbptg.html (Aug. 15, 2007).

U.S. EPA. (2007). "Envirofacts webpage-Safe drinking water information system (SDWIS)." 〈http://oaspub.epa.gov/enviro/sdw_form_ v2.create_page?state_abbr $=$ NC $\rangle$ (Aug. 15, 2007). 